\title{
The Future of Public Service:
}

\author{
Lessons from the Uncertainty and Disruption
}

\author{
Evi Maya Savira* \\ National Institute of Public Administration Republic Indonesia (NIPA) \\ Center for Innovation Management of Competency Development of State Civil Apparatus \\ Jakarta, Indonesia \\ *saejungsa@gmail.com
}

\begin{abstract}
Covid-19 has changed the way public service works. Since Covid-19 broke out in the early 2020, any organization has changed their behavior, strategies, and the way they run their businesses. Including public service should adjust their business process in flexible way as they can to secure their business. Massive disruption in private sector has triggered public sectors a long time ago before covid-19 arose. The emerged of covid-19 has increased uncertainty in public services surmounting numerous challenges at the same time is also leveraging significant opportunity. In this case, agility in public service is a prerequisite in adopting to the changing environment. Thus, what are lessons learned from the uncertainty and disruption for future of public service? That is the research question that would like to be answer within this paper. The purposes of this paper are to describe, and analysis lesson learned from the uncertainty and disruption for future of public service as well as what competencies are needed to address this challenges and opportunities. This study uses qualitative methods with series of virtual discussions with Indonesian Government experts as well as experts from Network of School of Government of OECD since March to November 2020. The results of this study are (1) lessons learned from the uncertainty and disruption for future of public service; (2) Key competencies needed in tackling the uncertainty and disruption for future of public services.
\end{abstract}

Keywords-future of public services, competencies in tackling uncertainty and disruption

\section{INTRODUCTION}

The $4^{\text {th }}$ industrial revolution has had an impact throughout the business environment including ways of working and thinking not to mention technological development. This revolution has called the first wave of uncertainty and disruption in major businesses including public sectors. Online platform has replaced the conventional business into digital platform. This major shift has created both externality and internality at the same time. The externality such as major closed in many conventional stores, shifting demand from conventional taxies to online based taxies with private ownership instead of firm-based taxy ownership; Bitcoin was the trend setter for block chain financial instrument which current has reached its peak in 2020; Many people loss their job since they changed most of labors with robots and artificial intelligent. In addition to that face-to-face interaction among humans become lesser than before.

As internality, this uncertainty and disruption are also creating more jobs in relating with data science, managing big data and any things which related with the internet of things. Moreover, this internality is also creating another success story of many startup companies in creating jobs and contributes to economy. Many people put their hopes to this internality to reduce the impact of the externality created from the $4^{\text {th }}$ industrial revolution. However, this positive impact has changed into unpromising situation due to the Covid-19 pandemic in 2020 .

Since Covid-19 outbreak in early 2020, it has created a situation which accumulated crisis and domino affects. This pandemic is not only about health crisis but also generating other crisis such as economy as global economic growth contracted globally by $4.4 \%$ in 2020 [1]. In addition to this situation, there were many people are being directly affected by the pandemic and climate-driven disasters all at once, and the world's poorest and most at- risk people are being hit first and hardest. Over 100 disasters took place between March 2020 (when the pandemic was announced) and six months later when this report was finalized, and over 50 million people were affected [2]. Physical distancing has brought consequence in labor as reported by the ILO [3], the declining of $14 \%$ in global working hours, equivalent to the loss of 400 millions full time workers; In other hand, the poverty has increased in the number of poor people by $88-155$ millions of people as reported by the World Bank [4]. The newly published Global Report on Food Crises 2020, which estimates that 135 million people in 55 countries currently face acute hunger as a result chiefly of conflict, the effects of climate change, and economic crises [5]. This domino effect has successfully formed uncertainty conditions and serious threat to the global community which eventually has increased enormous uncertainty in the public services.

Covid-19 has been changing the way public services around the globe operate in different way that they ever thought before. The massive call for digitalized any kind of 
services are mandatory to keep people live. Covid-19 pandemic, which requires physical distancing, has encouraged the digital based government as well as public services transformation to keep running their business. Remote government, work from home (WFH), work from office (WFO), working from anywhere (WFA) are the new modes of today's working styles in new normal era.

Social distancing is still the main effort to reduce the spread of the virus even today. Therefore, major call for digitalized government and public services are mandatory to make everyone sound and safe. Covid-19 as many experts and people said it is kind of blessing in disguised. Why was it called as a blessing? Covid-19 has surmounting numerous challenges at the same is also leveraging a significant opportunity

This paper describes and analysis the lessons learned from the uncertainty and disruption for future of public service as well as what competencies are needed to address this challenges and opportunities. The results of this study are (1) Lessons learned from the uncertainty and disruption for future of public service; (2) Key competencies needed in tackling the uncertainty and disruption for future of public services. The policy recommendations from this study will be used as further as study as well as input in competency development for the civil services in the era of uncertainty and disruption.

\section{LITERATURE REVIEW}

Literatures regarding the uncertainty and disruption in public sector has emerged since the $4^{\text {th }}$ revolution has propound impact to future feature of public sector as well private sector. Many international organizations such as OECD, and World Economic Forum (WEF) tried to figure out what the future of public services looks like within this uncertainty and disruption as part of our daily life. The OECD even produces several publications to grasp the essence of future of public service in leadership as well as the latest is the future of work in the public service preparing the workforce for change and uncertainty.

OECD in 2020 produced a publication concerning the leadership for a high performing civil service [6], this report has highlighted the future of work in the public service raises many questions about the role of technology and innovation in government, and how the public service needs to adapt to fast changing and unforeseen circumstance and crises. While nobody can predict the future, the OECD has developed a number of assumptions based on research, evidence, country experience and expert discussions. These suggest a massive workforce challenge in preparing the ground for effective use of new technologies and public sector innovation, by making public employment more forward looking, flexible to withstand crises, and fulfilling for civil servant [6]. OECD paper on the Future of Work in the Public Service [6] shows how public services will need to become more:
- Forward looking: In a fast-changing employment environment, with scarce skills and resources on one side and unpredictable changes on the other, robust strategic workforce planning based on foresight and resilience becomes a cornerstone of public employment policies. This suggests the need to be forward looking in terms of identifying skills, ensuring learning opportunities and managing knowledge.

- Flexible: Most civil service systems were established to emphasize stability and predictability, but agile responses to the coronavirus crisis have proven that flexible people management is possible in the face of complex, fast-moving public sector crises. This now presents a new opportunity to implement greater flexibility into standard operating procedures to enable the public sector to adapt as needed while maintaining transparency and accountability.

- Fulfilling: Public services will be required to be ever more competitive to attract scarce skill sets, in a tight labor market with ongoing fiscal pressures. This suggests the need to focus on providing fulfilling employment to an increasingly diverse labor market. This requires a focus on engagement and performance, leadership, and work design to ensure the public servants experience the value and impact of their work.

In addition to this report, WEF in 2020 published report concerning the future of jobs report 2020 provides us the timely insight needed to orient labor market and workers towards opportunity today and in the future of work, the report maps the jobs and skills of the future, tracking the pace of change and direction of travel [7]. Prior to that report, in 2019 OECD has launched OECD Employment Outlook 2019 [8]. Thriving in a digital world shows that digitalization threatens to widen and the best ways to bridge those gaps in the workplace, the classroom, at home, within countries and between countries [8]. According to this report, new digital technologies, including information and communication technologies (ICTs), artificial intelligence and robotics, are reshaping the way people live, work and learn [8]. This report presents both opportunity and inequalities are created by digitalization [7]. Furthermore, Ubaldi et al. [9] said that government face multiple challenges in how to incorporate these emerging technologies for public purposes; a paradigm shift will be essential to adopt systematic and whole of organization approaches to the digital transformation of the public sector [9].

The future work of public service first signal was the major shift in world jobs as reported by the World Economic Forum [7], there are 20 increasing demand of jobs and 20 decreasing demand of jobs, as follow (See Table 1): 
TABLE I. GLOBAL MAJOR SHIFT IN FutURE JOBS

\begin{tabular}{|c|c|c|c|}
\hline \multicolumn{2}{|r|}{ Increasing Demand } & \multicolumn{2}{|r|}{ Decreasing Demand } \\
\hline 1 & $\begin{array}{l}\text { Data Analyst and } \\
\text { Scientist }\end{array}$ & 1 & Data Entry Clerks \\
\hline 2 & $\begin{array}{l}\text { AI and Machine Learning } \\
\text { Specialist }\end{array}$ & 2 & $\begin{array}{l}\text { Administrative and Executive } \\
\text { Secretaries }\end{array}$ \\
\hline 3 & Big Data Specialist & 3 & $\begin{array}{l}\text { Accounting, Bookkeeping and } \\
\text { Payroll Clerks }\end{array}$ \\
\hline 4 & $\begin{array}{l}\text { Digital Marketing and } \\
\text { Strategies Specialists }\end{array}$ & 4 & Accountants and Auditors \\
\hline 5 & $\begin{array}{ll}\text { Process } & \text { Automation } \\
\text { Specialists } & \end{array}$ & 5 & $\begin{array}{l}\text { Assembly and Factory } \\
\text { Workers }\end{array}$ \\
\hline 6 & $\begin{array}{l}\text { Business Development } \\
\text { Professionals }\end{array}$ & 6 & $\begin{array}{l}\text { Business Services and } \\
\text { Administration Managers }\end{array}$ \\
\hline 7 & $\begin{array}{l}\text { Digital Transformation } \\
\text { Specialists }\end{array}$ & 7 & $\begin{array}{ll}\text { Client Information and } \\
\text { Customer Service Workers }\end{array}$ \\
\hline 8 & $\begin{array}{l}\text { Information } \quad \text { Security } \\
\text { Analysts }\end{array}$ & 8 & $\begin{array}{l}\text { General and Operations } \\
\text { Managers }\end{array}$ \\
\hline 9 & $\begin{array}{l}\text { Software } \quad \text { and } \\
\text { Applications Developers }\end{array}$ & 9 & $\begin{array}{l}\text { Mechanics and Machinery } \\
\text { Repairers }\end{array}$ \\
\hline 10 & $\begin{array}{l}\text { Internet of Things } \\
\text { Specialists }\end{array}$ & 10 & $\begin{array}{ll}\text { Material-Recording } & \text { and } \\
\text { Stock-Keeping Clerks } & \end{array}$ \\
\hline 11 & Project Managers & 11 & Financial Analysts \\
\hline 12 & $\begin{array}{l}\text { Business Services and } \\
\text { Administration Managers }\end{array}$ & 12 & Postal Service Clerks \\
\hline 13 & $\begin{array}{l}\text { Database and Network } \\
\text { Professionals }\end{array}$ & 13 & $\begin{array}{l}\text { Sales Rep., Wholesale and } \\
\text { Manuf., Tech. and Sci. } \\
\text { Products }\end{array}$ \\
\hline 14 & Robotics Engineers & 14 & Relationship Manager \\
\hline 15 & Strategic Advisors & 15 & $\begin{array}{l}\text { Bank Tellers and Related } \\
\text { Clerks }\end{array}$ \\
\hline 16 & $\begin{array}{l}\text { Management ad } \\
\text { Organization Analysts }\end{array}$ & 16 & $\begin{array}{l}\text { Door to Doors Sales, New and } \\
\text { Street Vendors }\end{array}$ \\
\hline 17 & FinTech Engineers & 17 & $\begin{array}{l}\text { Electronics and Telecons } \\
\text { Installers and repairers }\end{array}$ \\
\hline 18 & $\begin{array}{l}\text { Mechanics and } \\
\text { Machinery repairers }\end{array}$ & 18 & Human Resources Specialist \\
\hline 19 & $\begin{array}{l}\text { Organizational } \\
\text { Development Specialists }\end{array}$ & 19 & $\begin{array}{l}\text { Training and Development } \\
\text { Specialist }\end{array}$ \\
\hline 20 & $\begin{array}{ll}\text { Risk } & \text { Management } \\
\text { Specialist } & \\
\end{array}$ & 20 & Construction Labors \\
\hline
\end{tabular}

Source: WEF [7].

Both private and public sector now faces talent war to the increasing demand jobs within the industry. Digitalization in many aspects have brought to the consequences high demand on digital talent at any organization whilst the availability in the labor market is limited. Therefore, any organization tries their best to attract best talent to their organization.

The second signal was the Covid-19 pandemic. Covid-19 surmounting numerous challenges at the same time is also leveraging a significant opportunity in other word is a blessing in disguised. According to Ubaldi et al. [9], Covid-19 has challenged the status quo, blessing in disguise to shift and change organizational configuration to become more agile, networked, flexible and decentralized as shows from McKenzie organizational configuration degrees of change from minimal to drastic, as shows follow:
TABLE II. ORganizational CONFIGURATION DEgREES OF CHANGE

\begin{tabular}{|c|c|c|c|c|}
\hline \multicolumn{5}{|c|}{ Degree of Change } \\
\hline Minimal & & & & Drastic \\
\hline \multirow[t]{4}{*}{$\begin{array}{l}\text { Organizati } \\
\text { onak } \\
\text { Configurat } \\
\text { ion }\end{array}$} & Workplace & $\begin{array}{l}\text { Remin in } \\
\text { the } \\
\text { office }\end{array}$ & $\begin{array}{l}\text { Remote } \\
\text { working } \\
\text { enabled but } \\
\text { most people } \\
\text { still in the } \\
\text { office }\end{array}$ & $\begin{array}{l}\text { Remote } \\
\text { working is } \\
\text { fully accepted }\end{array}$ \\
\hline & $\begin{array}{l}\text { Organizati } \\
\text { onal } \\
\text { structure }\end{array}$ & $\begin{array}{l}\text { Tradition } \\
\text { al } \\
\text { pyramidi } \\
\text { cal } \\
\text { structure }\end{array}$ & $\begin{array}{l}\text { Networks of } \\
\text { project-based } \\
\text { work }\end{array}$ & $\begin{array}{l}\text { Learner, more } \\
\text { agile sturcture }\end{array}$ \\
\hline & $\begin{array}{l}\text { Decision- } \\
\text { making }\end{array}$ & $\begin{array}{l}\text { Centraliz } \\
\text { ed;comm } \\
\text { and and } \\
\text { control }\end{array}$ & $\begin{array}{l}\text { Morepowered } \\
\text { teams }\end{array}$ & $\begin{array}{l}\text { Strategy } \\
\text { remins } \\
\text { centrally set; } \\
\text { all } \\
\text { operational } \\
\text { decisions } \\
\text { decentralized }\end{array}$ \\
\hline & $\begin{array}{l}\text { Workforce } \\
\text { size }\end{array}$ & $\begin{array}{l}\text { Full-time } \\
\text { employe } \\
\text { es }\end{array}$ & $\begin{array}{l}\text { Management } \\
\text { remains full- } \\
\text { time, non- } \\
\text { management } \\
\text { shifts to 'gi } \\
\text { workiers }\end{array}$ & $\begin{array}{l}\text { 'Gig worker } \\
\text { utilized for all } \\
\text { workers }\end{array}$ \\
\hline
\end{tabular}

According to above table 2, Covid-19 has changed the organizational configuration from minimal degrees of change to drastic degrees of change. There are three types of change in workplace, organization structure, decision making and workforce size from minimal change, moderate change, or modification from minimal to drastic, and last the drastic one.

So, what is the future of public services? Gerson [11] said "The future of work in the public sector: digitalization, changing career expectations, and an ageing workforce). In addition, Network School of Governance OECD said the future of work in the public service: Agility and flexibility of the civil service (Civil services adapted quickly to changes); Reputation (Reputation of civil service may increase given that in majority of countries the civil service was key to implement measures); Cross-agency/cross-team collaboration (crisis has increased cross-agency and cross-team coordination and learning) [12]. Thus, the future of public service is the feature of public service in dealing with uncertainty and disruption environment with ability to fast learning, adaptable, forward-looking, collaborative, flexible as well as agility in dealing with dynamic environment. In conclusion, what are the key competencies are needed by the future of civil service to tackling the uncertainty and disruption? Gerson [11] has defined several key competencies are needed in tackling the uncertainty and disruption for future public service such as (See Table 3): 
TABLE III. OECD’s EMERGING SKILLSET

\begin{tabular}{|l|l|}
\hline \multicolumn{1}{|c|}{ Skills } & \multicolumn{1}{c|}{ Description } \\
\hline Digital Skill & $\begin{array}{l}\text { Digitalization created opportunity to } \\
\text { re-center work around innovation } \\
\text { and transformation through public } \\
\text { employees and their skills. }\end{array}$ \\
\hline Leadership & $\begin{array}{l}\text { Technical skills will have to be } \\
\text { complemented with behavioral ad } \\
\text { metacognitive skills. }\end{array}$ \\
\hline Skills for Resilience & $\begin{array}{l}\text { Resilience is a key capability for the } \\
\text { future, to address uncertainty and the } \\
\text { sense of increasing rates of change }\end{array}$ \\
\hline Strategic Workforce Planning, \\
Data and Security & $\begin{array}{l}\text { A forward-looking public service } \\
\text { requires coherent and robust works } \\
\text { force planning. A forward-looking } \\
\text { works force plan should begin a solid } \\
\text { understanding of current workforce. }\end{array}$ \\
\hline
\end{tabular}

Source: Gerson [11]

\section{RESEARCH METHODS}

This study uses qualitative methods such as desk study as well as with series of virtual discussions with Indonesian Government experts as well as experts from Network of School of Government of OECD since March to November 2020. The objective of these virtual discussions are to find formula and description on future public services in the era of uncertainty and disruption particularly with the Covid-19 impact to the public services.

\section{ANALYSIS AND DISCUSSION}

Uncertainty and disruption have created greater insecurity in public services. Covid-19 has called major changes for public services around the globe which never happen before. Remote working environment, digital based platform, working from home, working form office, and working from anywhere are the major shift in public services modes. Public sector should be well-preserved to keep everyone health, safe and economically secure.

Lessons learned from the Covid-19 in Indonesia bureaucracy experiences as mentioned by Muttaqin [10] in Indonesia, $88 \%$ of government jobs are estimated to be amenable to be done at home. In addition to that fact, higher education is also highly correlated with a higher proportion of jobs that can be done at home, as almost $80 \%$ of people with university education have jobs that can be done remotely at home [9]. World Bank [4] in their report regarding Indonesia Economic Prospects: The Long Road to Recovery said among 35 jobs categories in Indonesia, General Government activities placed around $80 \%$ can be done remotely at home, but the rest of government activities should be done on sites. Thus, human resource management policy in Indonesian civil service during the Covid-19 has massively applies flexible working arrangement which modified between working from home and working from office [10].

Therefore, according to Muttaqin [10] lesson learned for government's digital transformation which occur during the Covid-19 are: 1) Vision: Strengthen transformational leadership and digital capacity; 2) Institutional: Established a leaner structure, faster and accountable decision making process, comprehensive regulatory framework; 3) Culture: Transform the organizational set-up, culture, and mindsets; 4) System Thinking: Promote system thinking and the development of integrated approaches; 5) Data: Strategic management of data to enable data-driven policy making; 6) Infrastructure: Provide high-access broadband internet and safe and secure access to new technologies; 7) Resource: Mobilize resources and align priorities; 8) Capacity developers: Enhance the co-creation process and improving the capacity of education service providers; 9) Society: Develop capacities at the societal level to bridge the digital divide.

In addition, increasing demand at new jobs in labor market as well as in bureaucracy has turn on the alarm of talent war for both private and public sector. Some jobs are declining and other jobs increasing. This shifting requires fast response to ensure everyone has opportunity to enter the boat. New jobs demand is also generated externality in public sector such as up scaling of new skills in emerging skillset, investment in emerging skillset in uncertainty and disruption era, strong and flexible leadership approach, and foremost skills are considered and needs to be development are competence for resilience as already discussed by the OECD [11] .

During the discussion with NSG OECD in 2020 [12], there are some issues arose regarding what are the competencies need in future public service, and the proposal for the competencies as follow (See Table 4):

TABLE IV. Key Findings In AdDRESSING Future of Public SERvices

\begin{tabular}{|c|c|c|}
\hline Issues & Key Findings & Description \\
\hline \multirow[t]{3}{*}{$\begin{array}{c}\text { How has the crisis } \\
\text { shifted the } \\
\text { understanding of } \\
\text { public service and } \\
\text { public } \\
\text { employment? } \\
\text { What have we } \\
\text { learned? }\end{array}$} & $\begin{array}{l}\text { Agility and } \\
\text { flexibility of the } \\
\text { civil service }\end{array}$ & $\begin{array}{l}\text { Civil services adapted quickly } \\
\text { to changes, new working } \\
\text { environments and digital } \\
\text { tools, with some indicating } \\
\text { increases in efficiency and } \\
\text { higher job satisfaction } \\
\text { working from home, } \\
\text { depending on the work they } \\
\text { do, the tools they have, and } \\
\text { their home situation. }\end{array}$ \\
\hline & Reputation & $\begin{array}{l}\text { Reputation of civil service } \\
\text { may increase given that in } \\
\text { majority of countries the civil } \\
\text { service was key to implement } \\
\text { measures, provide for the } \\
\text { functioning of critical } \\
\text { infrastructure and in meeting } \\
\text { the overall needs of the } \\
\text { community. This positive } \\
\text { story needs to be } \\
\text { acknowledged and celebrated. }\end{array}$ \\
\hline & $\begin{array}{l}\text { Cross- } \\
\text { agency/cross-team } \\
\text { collaboration }\end{array}$ & $\begin{array}{l}\text { In many cases, the crisis has } \\
\text { increased cross-agency and } \\
\text { cross-team coordination and } \\
\text { learning. }\end{array}$ \\
\hline
\end{tabular}


TABLE IV. Cont.

\begin{tabular}{|c|c|c|}
\hline Issues & Key Findings & Description \\
\hline $\begin{array}{l}\text { How can we } \\
\text { further develop } \\
\text { resilience in our } \\
\text { public work } \\
\text { forces? What will } \\
\text { be the skills and } \\
\text { management } \\
\text { practices that we } \\
\text { need to build } \\
\text { resilience? }\end{array}$ & $\begin{array}{l}\text { The importance of } \\
\text { efficient use of } \\
\text { digital technology } \\
\text { and investing in } \\
\text { people and skills } \\
\text { to take advantage } \\
\text { of these tools }\end{array}$ & $\begin{array}{l}\text { In this way, the public service } \\
\text { needs to } \\
\text { fulfil the role of a learning } \\
\text { organization in which the } \\
\text { skills keep pace with new } \\
\text { technology and emerging } \\
\text { risks, such as cybersecurity. } \\
\text { This needs to extend to older } \\
\text { and younger employees to } \\
\text { create intergenerational } \\
\text { cooperation within the civil } \\
\text { service. }\end{array}$ \\
\hline \multirow[t]{2}{*}{$\begin{array}{c}\text { What are } \\
\text { opportunities for } \\
\text { rethinking public } \\
\text { employment when } \\
\text { this crisis is } \\
\text { behind us? What } \\
\text { risks will need to } \\
\text { be managed and } \\
\text { what pitfalls will } \\
\text { we have to avoid? }\end{array}$} & $\begin{array}{l}\text { Regarding } \\
\text { telework. It would } \\
\text { be essential to } \\
\text { find a good } \\
\text { balance between } \\
\text { working from } \\
\text { home and in the } \\
\text { office }\end{array}$ & $\begin{array}{l}\text { that telework is fair and } \\
\text { proportionate, while ensuring } \\
\text { work-life balance. In addition, } \\
\text { the crisis put the role of } \\
\text { leaders into focus and } \\
\text { demonstrated the importance } \\
\text { of crisis management skills } \\
\text { for leaders. }\end{array}$ \\
\hline & Mobility & $\begin{array}{l}\text { Two highlighted regarding } \\
\text { mobility: } \\
\square \text { Setting up working hubs } \\
\text { for staff to reduce travelling } \\
\text { and increase collaboration } \\
\text { across agencies. This idea } \\
\text { was echoed by UK and } \\
\text { Ireland. } \\
\square \text { Increase public service } \\
\text { mobility by identifying a } \\
\text { fixed surge reserve, which } \\
\text { could support critical roles } \\
\text { when needed to increase } \\
\text { flexibility. }\end{array}$ \\
\hline
\end{tabular}

Source: NSG-OECD [11]

Based above the NSG OECD discussion, therefore the skillset proposal for the future civil service as follow (See Table 5):

TABLE V. NSG OECD SKILLSET PROPOSAL FOR FUtURE CiVIL SERVICE

\begin{tabular}{|l|l|}
\hline \multicolumn{1}{|c|}{ SKILLS } & \multicolumn{1}{|c|}{ Description } \\
\hline $\begin{array}{l}\text { Cybersecurity, } \\
\text { governance, risk } \\
\text { management and } \\
\text { leadership }\end{array}$ & $\begin{array}{l}\text { Skills could focus in particular on short- } \\
\text { term readiness, while not neglecting a long- } \\
\text { term vision. Furthermore, collaboration } \\
\text { across department could be further } \\
\text { Enabling and supporting } \\
\text { incentivized. }\end{array}$ \\
$\begin{array}{l}\text { the current work force to } \\
\text { adapt to future crises and } \\
\text { to work together to } \\
\text { develop the skills needed }\end{array}$ & \\
\cline { 1 - 1 } $\begin{array}{l}\text { collaboration to cultivate } \\
\text { a culture of collaboration } \\
\text { and engagement with } \\
\text { peers }\end{array}$ & \\
\hline
\end{tabular}

Source: NSG-OECD [12]

To sum up the key competencies are needed for future public services, Gerson [10] organized as follows (See Table 6):
TABLE VI. A Future READY Public WorkForCE

\begin{tabular}{|l|l|l|}
\hline \multicolumn{1}{|c|}{ Forward Looking } & \multicolumn{1}{|c|}{ Flexible } & \multicolumn{1}{c|}{ Fulfilling } \\
\hline New emerging skillsets & $\begin{array}{l}\text { Working for anyone } \\
\text { from anywhere at any } \\
\text { time }\end{array}$ & $\begin{array}{l}\text { Diversity and } \\
\text { inclusion }\end{array}$ \\
\hline $\begin{array}{l}\text { Coherent strategic } \\
\text { workforce planning }\end{array}$ & Lifelong learning & Meaningful work \\
\hline Robust data & $\begin{array}{l}\text { Attracting acruiting a broader } \\
\text { recrue of skills from the } \\
\text { labor market }\end{array}$ & $\begin{array}{l}\text { Employee } \\
\text { experience, } \\
\text { engagement, and } \\
\text { performance }\end{array}$ \\
\hline
\end{tabular}

Source: Gerson [11]

\section{CONCLUSION}

Uncertainty is the real certainty itself. Both uncertainty and disruption bring both challenges and opportunity:

- Uncertainty should be treated as blessing in disguised instead worse-off.

- Post Covid-19, the way public service runs their business will be used current mode which modified among WFH, WFO and work from anywhere and anytime.

- Emerging skillset should be up scaling to the employees in order to get internalities form the insecurity.

- Future competencies as future skillset should be taken into consideration in any HRM decision as well as strategic decisions.

- Leadership is the key in tackling the crises into opportunity.

- Digital platform is the media, however soft kills which is human nature could not be replaced by any mean.

\section{REFERENCES}

[1] IMF, "World Economic Outlook Oktober 2020," 2020. [Online] Retrieved from: https://www.imf.org/en/Publications/WEO/Issues/2020/09/30/worldeconomic-outlook-october-2020

[2] IFRC, "World Disaster Report 2020", 2020. [Online]. Retrieved from: https://media.ifrc.org/ifrc/wpcontent/uploads/2020/11/20201116_WorldDisasters_Full.pdf

[3] ILO, ILO Monitor: COVID-19 and the world of work. Fifth edition Switzerland: Updated estimates and analysis, 30 June 2020.

[4] The World Bank, Indonesia Economic Prospects: The Long Road to Recovery. Washington, D.C.: The World Bank, July 2020.

[5] UNWFP, 2020 Global Report on Food Crises: Joint Analysis for Better Decisions. Italy: UNWFP, 2020

[6] D. Gerson, "Leadership for A High Performing Civil Service: Towards a Senior Civil Service System in OECD Countries," OECD Working Papers on Public Governance No. 40, OECD, 2020a.

[7] World Economic Forum (WEF), The Future Jobs Report 2020 Switzerland: World Economic Forum, October 2020.

[8] OECD, "OECD Employment Outlook 2019: The Future of Work. Paris: OECD Publishing, 2019. [Online]. Retrieved from: https://doi.org/10.1787/9ee00155-en 
[9] B. Ubaldi, E.M. Le Fevre, E. Petrucci, P. Marchionni, C. Biancalana, N. Hiltunen, ... and C. Yang, "State of the art in the use of emerging technologies in the public sector," OECD Working Papers on Public Governance No. 3, 2019. [Online]. Retrieved from: https://www.oecdilibrary.org/governance/state-of-the-art-in-the-use-of-emergingtechnologies-in-the-public-sector 932780bc-en

[10] T. Muttaqin, "Government Digitalization, and the Post Covid-19 Norm," November 30, 2020
[11] D. Gerson, "The Future of Work in the Public Service: Preparing the workforce for change and uncertainty," A discussion note for Network of Schools of Government-OECD, November 25, 2020, OECD, $2020 \mathrm{~b}$.

[12] NSG-OECD, "OECD Government After Shock: An unconventional event for unconventional times: The Future of Public Employment," a discussion result of the NSG-OECD discussion on November 18, 2020, NSG-OECD, 2020. 